\title{
Effect of bioamines on uptake of promastigotes of Leishmania donovani by hamster peritoneal macrophages
}

\author{
SMITA MITRA, LAGNAJITA GHOSH, PAMPA CHAKRABARTY, MADHUMITA BISWAS, \\ F. KATHLENE BHATTACHARYYA and D. K. GHOSH*
}

Indian Institute of Chemical Biology, Department of Immunochemistry, Leishmania Group, 4 Raja S C Mullick Road, Jadavpur, Calcutta-700 032, India

\begin{abstract}
Summary. Epinephrine and norepinephrine inhibit attachment of Leishmania donovani promastigotes to cultured hamster peritoneal macrophages. The inhibition was significant at catecholamine concentrations of $10^{-4}$ and $10^{-5} \mathrm{M}$ and occurred when they were added to the cell mixtures, or after pre-treatment of either macrophages or parasites. Inhibition of attachment after pre-treatment was less marked than when the catecholamines were added to parasite-cell mixtures. Similar results were obtained with dibutyryl cyclic AMP, cholera toxin, theophylline, and cadaverine which raise intracellular cyclic AMP (cAMP). Pretreatment of parasites or macrophages with the bioamines elevated the intracellular cAMP concentration. It is suggested that the inhibitory effect on the host-parasite interaction is mediated through cAMP.
\end{abstract}

\section{Introduction}

Macrophages are the host cells of Leishmania donovani, the aetiological agent of visceral leishmaniasis. The interaction between macrophages and the parasite involves recognition, binding and internalisation. Attachment of the parasite to the host cell is thought to be mediated by some form of receptorligand interaction ${ }^{1}$ and may involve $\mathrm{Fc}$ or $\mathrm{C} 3 \mathrm{~b}$ receptors or a lectin-like glycoprotein receptor on the macrophage cell surface. ${ }^{2,3}$

Although macrophage-parasite association is of prime importance for the initiation of infection, little is known about its regulation. Cyclic nucleotides and neurohormones are known to modulate several physiological and immunological reactions in phagocytic cells. Phagocytosis is retarded in the presence of catecholamines or cyclic AMP (cAMP). Whether this effect is due to internal or external concentrations of cAMP acting on the cell surface is uncertain. ${ }^{4,5}$ Macrophage phagocytosis of starch or opsonised sheep erythrocytes is inhibited by cAMP and agents that raise cAMP concentrations. We have evaluated the involvement of catecholamines in the initial interaction between promastigotes of $L$. donovani and macrophages.

\section{Materials and methods}

\section{Chemicals}

Epinephrine (bitartrate crystals), norephinephrine (bitartrate salt), $\mathrm{N}^{6}-2^{\prime}-0$-dibutyryl adenosine $3^{\prime}: 5^{\prime}$

Received 24 Jan. 1991; accepted 4 July 1991.

* Correspondence should be sent to Dr D. K. Ghosh. cyclic monophosphate (dibutyryl cAMP), theophylline, cholera toxin, cadaverine, HEPES buffer, Lglutamine and Giemsa stain were purchased from Sigma Chemical Co., St Louis, MO, USA. Medium RPMI 1640, fetal bovine serum (FBS), streptomycin and penicillin were purchased from Gibco, Grand Island, NY, USA. Sodium thioglycollate was purchased from Difco Laboratories, Detroit, MI, USA. cAMP assay kits were purchased from Amersham International plc, Amersham, Bucks.

\section{Macrophage culture}

The complete medium for macrophage culture was RPMI 1640 supplemented with FBS (heat-inactivated at $56^{\circ} \mathrm{C}$ for $30 \mathrm{~min}$ ) $10 \%, 25 \mathrm{mM}$ HEPES buffer, $4 \mathrm{mM}$ L-glutamine, streptomycin $100 \mu \mathrm{g} / \mathrm{ml}$ and penicillin $100 \mathrm{U} / \mathrm{ml}$. Macrophages were harvested from the peritoneal cavity of Golden Syrian hamsters which had been stimulated 3 days earlier by intraperitoneal (i.p.) injection of thioglycollate broth $4 \% \mathrm{w} / \mathrm{v}$. On the day of an experiment, each animal was given $20 \mathrm{ml}$ of serum-free RPMI medium by i.p. injection. After gentle abdominal massage, peritoneal fluid was collected, pooled and centrifuged aseptically. The pellet was resuspended in complete RPMI medium. Cells were counted in a haemocytometer. Monolayers on glass coverslips $\left(22 \mathrm{~mm}^{2}\right)$ were prepared from $0 \cdot 2-\mathrm{ml}$ samples $\left(1 \times 10^{6}\right.$ cells $\left./ \mathrm{ml}\right)$ in $35-\mathrm{mm}$ sterile petri dishes. ${ }^{6}$ They were incubated in $\mathrm{CO}_{2} 5 \%$-air $95 \%$ at $37^{\circ} \mathrm{C}$ for $2 \mathrm{~h}$ to allow adhesion. Non-adherent cells were removed by washing with supplemented RPMI 1640 without FBS, $2 \mathrm{ml}$ of fresh complete culture medium was added to each petri dish, and the macrophages were incubated overnight at $37^{\circ} \mathrm{C} .{ }^{7,8}$ 


\section{L. donovani promastigotes}

These were of strain UR6 and were routinely cultured in modified Ray's medium as described elsewhere. ${ }^{9}$ Promastigotes were suspended in complete RPMI medium, washed twice and counted in a haemocytometer after suitable dilution.

\section{Assay}

A promastigote-macrophage association assay was developed to measure the effect of the test drugs on parasite adherence to the host cell. The assays were done under three experimental conditions to assess the site of action of the drugs.

In test $A$, the effect of drugs and chemicals on the ability of macrophages to take up untreated parasites was assessed. The monolayer was pre-treated with the test agent in $1 \mathrm{ml}$ of medium at appropriate concentrations for $1 \mathrm{~h}$ at $37^{\circ} \mathrm{C}$ and then washed in agent-free complete RPMI 1640. Parasite suspension ( $1 \mathrm{ml}$ ) was added to the monolayer in the promastigotes: macrophage ratio $5: 1$ and the mixture was incubated for $1 \mathrm{~h}$ at $37^{\circ} \mathrm{C}$. Non-adherent parasites were removed by rinsing twice in the dish with serum-free RPMI 1640 medium. The monolayer was then fixed with methanol and treated with Giemsa stain.

Test $B$ measured the effect of drugs on promastigote adherence to untreated macrophages. The test differed in that the parasite suspensions were pre-treated with the test agent by incubating for $1 \mathrm{~h}$ at $26^{\circ} \mathrm{C}$. Samples were taken after $1 \mathrm{~h}$ to check parasite motility. After $1 \mathrm{~h}$, the parasite suspensions were washed twice by centrifugation at $900 \mathrm{rpm}$ for $5 \mathrm{~min}$ before they were resuspended in complete RPMI 1640 medium and added to the untreated monolayers. After incubation at $37^{\circ} \mathrm{C}$ for $1 \mathrm{~h}$, the monolayers were rinsed, fixed and stained as before.

Test $\mathrm{C}$ measured the effects of the presence of agents on parasite-macrophage interaction. It differed in that the agents were added together with the parasites to the macrophage monolayer without any pre-treatment and incubated for $1 \mathrm{~h}$ at $37^{\circ} \mathrm{C}$ before rinsing and staining.

Each experiment was done at least three times with matching agent-free controls. Coverslips were examined by microscopy $(\times 400)$. Counts of at least 100 macrophages were done in each case to determine the number with attached parasites and the number of parasites bound per cell. Data were analysed statistically by Students' $t$ test.

\section{Cyclic AMP assay}

Macrophage and parasite preparations used to measure cAMP levels were prepared as follows. Adherent macrophages (as described above) were removed from sterile coverslips with a "rubber policeman" and suspended in RPMI 1640 medium at a concentration of $10^{7}$ cells $/ \mathrm{ml}$. Parasites were similarly suspended in RPMI 1640 medium at $10^{7}$ cells $/ \mathrm{ml}$. Both macrophage and parasite cell suspension were centrifuged for $15 \mathrm{~min}$ at $3000 \mathrm{rpm}$. Cell pellets were resuspended in $2 \mathrm{ml}$ of $\mathrm{PBS}, \mathrm{pH} \mathrm{7.4}$, and an equal volume of trichloroacetic acid (TCA) 10\% was added to each tube and mixed thoroughly. The mixtures were centrifuged after $15 \mathrm{~min}$ and the supernate of each tube was extracted four times with water-saturated ether to remove TCA. The water layer was lyophilised and reconstituted with $130 \mu \mathrm{l}$ of sodium acetate buffer, $\mathrm{pH} 6 \cdot 2 ; 50-\mu \mathrm{l}$ volumes were used to measure cAMP with a commercial radioimmunoassay kit (Amersham International) according to the manufacturer's instructions. Similar procedures were performed with treated macrophages and parasites. Results were expressed as the picomolar concentration of cAMP in relation to a reference curve obtained with solutions of cAMP of known concentration.

\section{Results}

Attachment of $L$. donovani to hamster peritoneal macrophage monolayers was inhibited by epinephrine and norepinephrine after pre-treatment of either the macrophages or the parasites with the catecholamines (table I, A and B). Adhesion of L. donovani to hamster peritoneal macrophages was also inhibited by both agents when these were incubated with the parasitemacrophage preparation (table I,C). At concentrations of $10^{-4} \mathrm{M}$ and $10^{-5} \mathrm{M}$, the catecholamines significantly reduced the percentage of macrophages with attached parasites. The reduction seen at $10^{-6} \mathrm{M}$ was not significant (table I).

The effect of these catecholamines on the number of parasites bound per macrophage are shown in table II. By this criterion it was noted that pre-treatment of parasites (test B) inhibited attachment less than did tests A and C. Pre-treatment of the parasite did not cause significant change in motility at $1 \mathrm{~h}$.

Agents known to raise cellular cAMP, i.e., cholera toxin, theophylline and cadaverine, were then tested. All these agents inhibited parasite-macrophage binding. Pre-treatment of macrophages with these agents produced greater inhibition than was found with pretreatment of parasites. All the agents significantly reduced both the proportion of macrophages with attached parasite and the number of parasites bound per cell (table III).

Similarly, direct addition of dibutyryl cAMP significantly reduced the percentage of infected macrophages (table IV) and the number of parasites attached per macrophage (table V).

A significant rise in intracellular cAMP level was observed when the parasites were pre-treated with adrenaline and noradrenaline. The stimulation was greater with adrenaline than with noradrenaline. An increase of the intracellular cAMP level was also noted when macrophages were pre-treated with these bioam- 
Table I. Effect of catecholamines on $L$. donovani attachment with hamster peritoneal macrophages

\begin{tabular}{|c|c|c|c|c|c|c|c|}
\hline \multirow{3}{*}{$\begin{array}{l}\text { Experimental } \\
\text { condition }\end{array}$} & \multicolumn{7}{|c|}{ Percentage of macrophages attached with $L$. donovani (mean and SEM) } \\
\hline & \multirow{2}{*}{ Control } & \multicolumn{3}{|c|}{ Epinephrine (M) } & \multicolumn{3}{|c|}{ Norepinephrine (M) } \\
\hline & & $10^{-4}$ & $10^{-5}$ & $10^{-6}$ & $10^{-4}$ & $10^{-5}$ & $10^{-6}$ \\
\hline \multicolumn{8}{|l|}{ Test A. } \\
\hline $\begin{array}{l}\text { Pre-treated macro- } \\
\text { phages }\end{array}$ & $63 \cdot 1$ SEM $2 \cdot 5$ & $\begin{array}{c}\text { 44.7 SEM } 3 \cdot 3 \ddagger \\
(29 \cdot 2 \%)^{*}\end{array}$ & $\begin{array}{c}51 \cdot 0 \text { SEM } 3.6 \\
(19 \cdot 1 \%)\end{array}$ & $\begin{array}{l}56 \cdot 7 \text { SEM } 4 \cdot 3 \\
(10 \cdot 2 \%)\end{array}$ & $\begin{array}{c}46 \cdot 7 \text { SEM } 3 \cdot 5 \dagger \\
(26 \cdot 0 \%)\end{array}$ & $\begin{array}{c}50 \cdot 0 \text { SEM } 2 \cdot 1 \ddagger \\
(20 \cdot 7 \%)\end{array}$ & $\begin{array}{l}56 \cdot 7 \text { SEM } 4.3 \\
(10 \cdot 2 \%)\end{array}$ \\
\hline \multicolumn{8}{|l|}{ Test B. } \\
\hline Pre-treated parasites & $52 \cdot 7$ SEM $2 \cdot 12$ & $\begin{array}{c}37 \cdot 0 \text { SEM } 2 \cdot 1 \dagger \\
(29 \cdot 7 \%)\end{array}$ & $\begin{array}{c}41 \cdot 7 \mathrm{SEM} 2 \cdot 7 \S \\
(20 \cdot 9 \%)\end{array}$ & $\begin{array}{l}\text { 48.3 SEM } 3 \cdot 2 \\
(8 \cdot 3 \%)\end{array}$ & $\begin{array}{c}40 \cdot 0 \text { SEM } 2 \cdot 4 \ddagger \\
(24 \cdot 1 \%)\end{array}$ & $\begin{array}{c}41 \cdot 0 \text { SEM } 2 \cdot 3 \S \\
(22 \cdot 2 \%)\end{array}$ & $\begin{array}{c}\text { 48.7 SEM } 2.6 \\
(11 \cdot 5 \%)\end{array}$ \\
\hline \multicolumn{8}{|l|}{ Test C. } \\
\hline $\begin{array}{l}\text { Macrophages and para- } \\
\text { sites treated together }\end{array}$ & $62 \cdot 1$ SEM $2 \cdot 63$ & $\begin{array}{c}44 \cdot 3 \text { SEM } 2 \cdot 9 \ddagger \\
(28.6 \%)\end{array}$ & $\begin{array}{c}52 \cdot 7 \text { SEM } 3 \cdot 3 \\
(15 \cdot 2 \%)\end{array}$ & $\begin{array}{c}54 \cdot 3 \text { SEM } 4 \cdot 3 \\
(12 \cdot 5 \%)\end{array}$ & $\begin{array}{c}37 \cdot 0 \text { SEM } 3 \cdot 5 \dagger \\
(40.4 \%)\end{array}$ & $\begin{array}{c}51 \cdot 3 \mathrm{SEM} 4 \cdot 7 \\
(17 \cdot 3 \%)\end{array}$ & $\begin{array}{c}\text { 54.0 SEM } 3 \cdot 4 \\
(13.0 \%)\end{array}$ \\
\hline
\end{tabular}

Table II. Effect of catecholamines on macrophage- $L$. donovani interaction

\begin{tabular}{|c|c|c|c|c|}
\hline \multirow[b]{2}{*}{ Agent } & \multirow[b]{2}{*}{$\begin{array}{c}\text { Molar } \\
\text { concentration }\end{array}$} & \multicolumn{3}{|c|}{ Number of $L$. donovani attached per macrophage (mean and SEM) } \\
\hline & & $\begin{array}{c}\text { Test A } \\
\text { Pre-treated } \\
\text { macrophages }\end{array}$ & $\begin{array}{c}\text { Test B } \\
\text { Pre-treated } \\
\text { parasites }\end{array}$ & $\begin{array}{l}\text { Test C } \\
\text { Parasites and } \\
\text { macrophages } \\
\text { treated together }\end{array}$ \\
\hline Epinephrine & $\begin{array}{c}0 \\
10^{-4} \\
0 \\
10^{-5} \\
10^{-6}\end{array}$ & $\begin{array}{l}\text { 3.28 SEM } 0.54(0)^{*} \\
\text { 1.53 SEM } 0.01 \dagger(53 \%) \\
3.04 \text { SEM } 0.43(0) \\
1.84 \text { SEM } 0.20(39 \%) \\
2.20 \text { SEM } 0.40(28 \%)\end{array}$ & $\begin{array}{l}\text { 2.50 SEM } 0.24(0) \\
1.61 \text { SEM } 0.08 \dagger(36 \%) \\
2.50 \text { SEM } 0.24(0) \\
1.71 \text { SEM } 0.14 \dagger(32 \%) \\
2.19 \text { SEM } 0.16(12 \%)\end{array}$ & $\begin{array}{l}\text { 3.28 SEM } 0.54(0) \\
\text { 1.64 SEM } 0.19 \dagger(50 \%) \\
3.04 \text { SEM } 0.43(0) \\
1 \cdot 70 \text { SEM } 0.08 \dagger(44 \%) \\
2.00 \text { SEM } 0.26(34 \%)\end{array}$ \\
\hline Norepinephrine & $\begin{array}{c}0 \\
10^{-4} \\
0 \\
10^{-5} \\
10^{-6}\end{array}$ & $\begin{array}{l}\text { 3.28 SEM } 0.54(0) \\
1.55 \text { SEM } 0.05 \dagger(53 \%) \\
3.04 \text { SEM } 0.43(0) \\
1.74 \text { SEM } 0.19 \dagger(43 \%) \\
2.12 \text { SEM } 0.35(30 \%)\end{array}$ & $\begin{array}{l}2.50 \text { SEM } 0.24(0) \\
1.58 \text { SEM } 0.07 \dagger(37 \%) \\
2.50 \text { SEM } 0.24(0) \\
1.76 \text { SEM } 0.06 \dagger(30 \%) \\
2.17 \text { SEM } 0.18(13 \%)\end{array}$ & $\begin{array}{l}\text { 3.28 SEM } 0.54(0) \\
\text { 1.67 SEM } 0.10 \dagger(49 \%) \\
3.04 \text { SEM } 0.43(0) \\
1.74 \text { SEM } 0.06 \dagger(43 \%) \\
1.94 \text { SEM } 0.10(36 \%)\end{array}$ \\
\hline
\end{tabular}

* Figures in parenthesis are results expressed as percentage inhibition. $\dagger \mathrm{p}<0.05$.

ines. The stimulatory effect of these bioamines on cAMP formation was higher at $10^{-4} \mathrm{M}$ than that at $10^{-5} \mathrm{M}$. The extent of stimulation by adrenaline and noradrenaline was almost the same (table VI).

\section{Discussion}

This study reveals that catecholamines, added cAMP and agents that elevate intracellular cAMP, inhibit the attachment of $L$. donovani to cultured macrophages. Epinephrine, norepinephrine, dibutyryl cAMP, theophylline, cadaverine and cholera toxin, each significantly reduced the attachment of parasites to macrophages, regardless of their mode of application. Inhibition took place in the presence of the agents in the incubation mixture and also after pre- treatment of either cell type. Thus, both ability of the macrophage to take up the parasite and of the parasite to adhere to macrophages were sensitive to the agents.

Leishmania-macrophage interaction is critical for the initiation of visceral leishmaniasis. This is thought to involve specific recognition and interaction of lectin-like receptors on the macrophage with sugar ligands on the parasite surface. ${ }^{10,11}$ Attachment is followed by a complex series of events. It is possible to recognise internalisation or phagocytosis by the macrophage, followed by transformation of the parasite, leading to its proliferation. ${ }^{3}$ Macrophage interaction with leishmania, ${ }^{12}$ and trypanosomes ${ }^{5}$ is sensitive to cAMP and agents that induce it. These agents have also been shown to be important in models of phagocytosis ${ }^{4,13}$ but the site and nature of this modulation is not understood. 
Table III. Effect of cholera toxin, theophylline and cadaverine on macrophage- $L$. donovani interaction

\begin{tabular}{|c|c|c|c|}
\hline $\begin{array}{l}\text { Experimental } \\
\text { conditions }\end{array}$ & Agents & $\begin{array}{l}\text { Percentage of macrophages } \\
\text { with attached } L \text {. donovani (mean and } \\
\text { SEM) }\end{array}$ & $\begin{array}{c}\text { Average number of } L . \text { donovani } \\
\text { attached per macrophage (mean and SEM) }\end{array}$ \\
\hline \multirow[t]{10}{*}{$\begin{array}{l}\text { Test A. Pre-treated } \\
\text { macrophages }\end{array}$} & None & 76.4 SEM 3.83 & $2.89 \mathrm{SEM} 0.19$ \\
\hline & Cholera toxin & & \\
\hline & $50 \mathrm{ng} / \mathrm{ml}$ & $40 \cdot 0$ SEM $3.23+(47 \cdot 7 \%)$ & $0.80 \mathrm{SEM} 0.05 \uparrow$ \\
\hline & $25 \mathrm{ng} / \mathrm{ml}$ & $55 \cdot 2$ SEM $3.22 \ddagger(27.8 \%)$ & $1 \cdot 10 \mathrm{SEM} 0.14 \dagger$ \\
\hline & Theophylline & & \\
\hline & $10^{-4} \mathrm{M}$ & 54.4 SEM $2.58 \ddagger(28.8 \%)$ & $1 \cdot 14$ SEM $0.12 \dagger$ \\
\hline & $10^{-5} \mathrm{M}$ & 55.2 SEM $2.86 \quad(27.8 \%)$ & 1.11 SEM $0.08 \dagger$ \\
\hline & Cadaverine & & \\
\hline & $10^{-4} \mathrm{M}$ & 59.6 SEM $3.77 \S(22.0 \%)$ & 1.32 SEM $0.14 \dagger$ \\
\hline & $10^{-5} \mathrm{M}$ & 62.0 SEM $3.18+(18.9 \%)$ & 1.56 SEM $0.15 \dagger$ \\
\hline \multirow{10}{*}{$\begin{array}{c}\text { Test B. Pre-treated } \\
\text { parasites }\end{array}$} & None & 62.4 SEM 1.94 & 1.76 SEM 0.11 \\
\hline & Cholera toxin & & \\
\hline & $50 \mathrm{ng} / \mathrm{ml}$ & 54.8 SEM $2.339(12.2 \%)$ & 1.32 SEM 0.09§ \\
\hline & $25 \mathrm{ng} / \mathrm{ml}$ & 57.6 SEM $3.02 \quad(7.7 \%)$ & 1.40 SEM $0.14 \pi$ \\
\hline & Theophylline & & \\
\hline & $10^{-4} \mathrm{M}$ & $49 \cdot 6$ SEM $2.74 \ddagger(20.6 \%)$ & $1 \cdot 15$ SEM $0.07 \dagger$ \\
\hline & $10^{-5} \mathrm{M}$ & $55 \cdot 2$ SEM $3.13(11.6 \%)$ & $1 \cdot 16$ SEM 0.07t \\
\hline & Cadaverine & & \\
\hline & $10^{-4} \mathrm{M}$ & 48.8 SEM $2.25 \ddagger(21.8 \%)$ & 1.28 SEM $0.12 \ddagger$ \\
\hline & $10^{-5} \mathrm{M}$ & 54.4 SEM $2.61 \quad(12.9 \%)$ & 1.35 SEM $0 \cdot 10 \ddagger$ \\
\hline
\end{tabular}

*Figures in parenthesis are results expressed as percentage inhibition.

$+\mathrm{p}<0.001$.

$\pm \mathrm{p}<0.01$

$\S \mathrm{p}<0.02$.

Ip $<0.05$.

Table IV. Effect of cAMP on attachment of $L$. donovani with hamster peritoneal macrophages

\begin{tabular}{|c|c|c|c|c|}
\hline \multirow{2}{*}{$\begin{array}{l}\text { Experimental } \\
\text { condition }\end{array}$} & \multicolumn{4}{|c|}{ Percentage of macrophages with attached $L$. donovani (mean and SEM) } \\
\hline & Control & $10^{-4} \mathrm{M}$ & $10^{-5} \mathrm{M}$ & $10^{-6} \mathrm{M}$ \\
\hline $\begin{array}{l}\text { Test A. Pre-treated } \\
\text { macrophages }\end{array}$ & $63 \cdot 11 \mathrm{SEM} 2 \cdot 5$ & $\begin{array}{c}44.3 \text { SEM } 3 \cdot 2 \dagger \\
(29 \cdot 8 \%)^{*}\end{array}$ & $\begin{array}{c}50 \cdot 0 \text { SEM } 2 \cdot 8 \ddagger \\
(20 \cdot 7 \%)\end{array}$ & $\begin{array}{c}56.33 \text { SEM } 3.3 \\
(10.7 \%)\end{array}$ \\
\hline $\begin{array}{c}\text { Test B. Pre-treated } \\
\text { parasites }\end{array}$ & $80 \cdot 0$ SEM $4 \cdot 33$ & $\begin{array}{c}56.40 \text { SEM } 3.86 \ddagger \\
(42 \%)\end{array}$ & $\begin{array}{c}\text { 68.0 SEM } 3.06 \\
(51 \%)\end{array}$ & $\begin{array}{c}75 \cdot 20 \text { SEM } 5 \cdot 44 \\
(54 \%)\end{array}$ \\
\hline $\begin{array}{l}\text { Test C. Macrophages and } \\
\text { parasites treated } \\
\text { together }\end{array}$ & $62 \cdot 1$ SEM $2 \cdot 63$ & $\begin{array}{c}\text { 46.66 SEM } 3 \cdot 5 \S \\
(24.9 \%)\end{array}$ & $\begin{array}{c}47 \cdot 33 \text { SEM } 2 \cdot 8 \S \\
(23 \cdot 8 \%)\end{array}$ & $\begin{array}{c}\text { 55.66 SEM } 5 \cdot 6 \\
(10 \cdot 4 \%)\end{array}$ \\
\hline
\end{tabular}

* Figures in parenthesis are results expressed as percentage inhibition.

$+\mathrm{p}<0.01$.

$\pm \mathrm{p}<0.02$.

$\S \mathrm{p}<0.05$

Table V. Effect of cAMP on macrophage-L. donovani interaction

\begin{tabular}{|c|c|c|c|}
\hline \multirow[b]{2}{*}{$\begin{array}{c}\text { Molar concentration } \\
\text { of cAMP }\end{array}$} & \multicolumn{3}{|c|}{ Number of $L$. donovani attached per macrophage (mean and SEM) } \\
\hline & $\begin{array}{c}\text { Test A } \\
\text { Pre-treated } \\
\text { macrophage }\end{array}$ & $\begin{array}{c}\text { Test B } \\
\text { Pre-treated parasites }\end{array}$ & $\begin{array}{c}\text { Test C } \\
\text { Parasites and } \\
\text { macrophages } \\
\text { treated together }\end{array}$ \\
\hline $\begin{array}{c}0 \\
10^{-4}\end{array}$ & $\begin{array}{l}3.28 \text { SEM } 0.54(0)^{*} \\
1.47 \text { SEM } 0.23 \dagger\left(55^{\circ}\right)\end{array}$ & $\begin{array}{l}2.50 \text { SEM } 0.24 \quad(0) \\
1.58 \text { SEM } 0.10 \dagger(37 \%)\end{array}$ & $\begin{array}{l}3.28 \text { SEM } 0.54 \quad(0) \\
1.52 \text { SEM } 0.09 \dagger(54 \%)\end{array}$ \\
\hline $\begin{array}{l}0 \\
10^{-5} \\
10^{-6}\end{array}$ & $\begin{array}{ll}3.04 \text { SEM } 0.43 & (0) \\
1.75 \text { SEM } 0.24 & (42 \%) \\
2.00 \text { SEM } 0.32 & (34 \%)\end{array}$ & $\begin{array}{l}2.50 \text { SEM } 0.24 \quad(0) \\
1.73 \text { SEM } 0.08+(31 \%) \\
2.05 \text { SEM } 0.10 \quad(18 \%)\end{array}$ & $\begin{array}{l}3.04 \text { SEM } 0.43 \quad(0) \\
1.73 \text { SEM } 0.10 \dagger(43 \%) \\
1.90 \text { SEM } 0.28 \quad(37 \%)\end{array}$ \\
\hline
\end{tabular}

* Figures in parenthesis are results expressed as percentage inhibition.

t $\mathrm{p}<0.05$. 
Table VI. Effect of catecholamines on intracellular concentrations of cAMP of parasites and macrophages

\begin{tabular}{|c|c|c|c|}
\hline \multirow{2}{*}{ Agent present } & \multirow{2}{*}{$\begin{array}{l}\text { Concentration } \\
\text { (M) }\end{array}$} & \multicolumn{2}{|c|}{ pM cAMP $/ 10^{7}$ cell (mean and SEM) } \\
\hline & & L. donovani & Macrophage \\
\hline Control & $\ldots$ & 0.63 SEM 0.05 & 2.77 SEM 0.42 \\
\hline Adrenaline & $\begin{array}{l}10^{-4} \\
10^{-5}\end{array}$ & $\begin{array}{c}\text { 6.5 SEM } 0.58^{*} \\
2 \cdot 17 \text { SEM } 0 \cdot 17^{*}\end{array}$ & $\begin{array}{c}\text { 10.9 SEM } 0.91 \dagger \\
\text { 3.2 SEM } 0.43\end{array}$ \\
\hline Noradrenaline & $\begin{array}{l}10^{-4} \\
10^{-5}\end{array}$ & $\begin{array}{l}\text { 3.2 SEM } 0.41 \dagger \\
1.0 \text { SEM } 0.09 \ddagger\end{array}$ & $\begin{array}{l}\text { 9.1 SEM } 0.8 \dagger \\
2.5 \text { SEM } 0.34\end{array}$ \\
\hline
\end{tabular}

cAMP inhibition of peritoneal macrophagocytosis was demonstrated with opsonised sheep erthyrocytes ${ }^{14}$ and Candida albicans ${ }^{15}$ and the latter authors also described inhibition of polymorphonuclear leukocyte phagocytosis. Interestingly, cAMP at lower concentrations reportedly stimulates uptake of aggregated bovine serum albumin by macrophages. ${ }^{16}$ In the Trypanosoma cruzi-macrophage model, cAMP has been found to inhibit initial attachment. ${ }^{5}$

Phosphodiesterase inhibitors such as theophylline increase cAMP levels in leishmanias. ${ }^{12}$ They also inhibit macrophagocytosis of T. cruzi ${ }^{5}$ and the inhibition was associated with a rise in cell cAMP. ${ }^{5}$ As in the present study, neither motility nor viability of the parasite was affected by the agents. ${ }^{5}$

Therefore, there seems ample evidence that cAMP is a modulator of host-parasite interactions in several

\section{References}

1. Imber MJ, Pizzo SV, Johnston WJ, Adams DO. Selective diminution of the binding of mannose by murine macrophages in the late stages of activation. J Biol Chem 1982; 257: 5129-5135.

2. Zenian A, Kierszenbaum F. Inhibition of macrophage-Trypanosoma cruzi interaction by concanavalin $\mathrm{A}$ and differential binding of bloodstream and culture forms to the macrophage surface. $J$ Parasitol $1982 ; 68: 408-451$.

3. Blackwell JM, Alexander J. The macrophage and parasitic protozoa. Trans R Soc Trop Med Hyg 1983: 77: 636-645.

4. Ignarro LJ, Cech SY. Bidirectional regulation of lysosomal enzyme secretion and phagocytosis in human neutrophils by guanisine $3^{\prime}, 5^{\prime}$-monophosphate and adenosine $3^{\prime}, 5^{\prime}$ monophosphate (39232). Proc Soc Exp Biol Med 1976; 151 : 448-452.

5. Wirth JJ, Kierszembaum F. Inhibitory action of elevated levels of adenosine- $3^{\prime}: 5^{\prime}$ cyclic monophosphate on phagocytosis: effects on macrophage-Trypanosoma cruzi interaction. $J$ Immunol 1982; 129: 2759-2762.

6. Chang K-P. Hamster peritoneal macrophages in vitro: substratum adhesion, spreading, phagocytosis and phagolysosome formation. In vitro $1978 ; 14: 663-674$.

7. Cohn ZA, Benson B. The differentiation of mononuclear phagocytes: morphology, cytochemistry, and biochemistry. J Exp Med 1965; 121: 153-169.

8. Akiyama HJ, Taylor JC. Effect of macrophage engulfment and temperature on the transformation process of Leishmania donovani. Am J Trop Med Hyg 1970; 19: 747-754. species and with several phagocytic cells. A cAMPdependent protein kinase has not so far been demonstrated in leishmanias. However, our study shows that leishmania promastigotes, as well as the macrophages, are sensitive to cAMP manipulation in such a way as to alter their ability to attach when they subsequently interact. Elevation of intracellular cAMP concentration has also been noted in the presence of bioamines, which suggests that the inhibitory effect on hostparasite interaction is mediated through cAMP. However, the exact mechanism through which cAMP modulates the interaction is not known. Nevertheless, our evidence suggests that cAMP acts at the key steps of cell attachment by modulating surface receptors in both host and parasite in $L$. donovani infection.

Financial assistance from the Indian Council of Medical Research, UNDP is gratefully acknowledged.

9. Mukerji K, Ghosh DK. Cytoplasmic and membrane antigens of Leishmania donovani. IRCS Med Sci (Cell and membrane biology) 1983 ; 11 : 785-786.

10. Chang K-P. Leishmania donovani-macrophage binding mediated by surface glycoprotein antigens:characterization in vitro by a radioisotopic assay. Mol Biochem Parasitol $1981 ; 4: 67-76$.

11. Palatnik CB. Inhibition of Leishmania donovani promastigote internalization into murine macrophages by chemically defined parasite glycoconjugate ligands. Infect Immun 1989; 57: 754-763.

12. Walter RD, Buse E, Ebert F. Effect of cyclic AMP on transformation and proliferation of Leishmania cells. Tropenmedizin und Parasitologie $1978 ; 29$ : 439-442.

13. Cox JP, Karnovsky ML. The depression of phagocytosis by exogenous cyclic nucleotides, prostaglandins, and theophylline. J Cell Biol 1973; 59: 480-490.

14. Lime AO, Javierre MQ, Dias da Silva W, Camara DS. Immunological phagocytosis:effect of drugs on phosphodiesterase activity. Experientia 1974 ; 30 : 945-946.

15. Bourne HR, Lehrer RL, Cline MJ, Melmon KL. Cyclic 3', $5^{\prime}-$ adenosine monophosphate in human leukocyte:synthesis, degradation, and effects on neutrophil candidacidal activity. J Clin Invest 1971; 50: 920-929.

16. Weissmann G, Dukor P, Sessa G. Studies on lysosomes: mechanisms of enzyme release from endocytic cells and a model for latency in vitro. In: Forscher BK, Houck JC (eds) Immunopathology of inflammation. Amsterdam, Excerpta Medica Foundation. (Excerpta Medica International Congress Series No. 229) 1971: 107-117. 